\title{
Front Matter: Volume 8566
}

, "Front Matter: Volume 8566," Proc. SPIE 8566, Lasers in Dentistry XIX, 856601 (25 March 2013); doi: 10.1117/12.2022373

SPIE. Event: SPIE BiOS, 2013, San Francisco, California, United States 


\section{PROGRESS IN BIOMEDICAL OPTICS AND IMAGING}

Vol. 14 No. 2

\section{Lasers in Dentistry XIX}

Peter Rechmann

Daniel Fried

Editors

3 February 2013

San Francisco, California, United States

Sponsored and Published by

SPIE

\section{Volume 8566}


The papers included in this volume were part of the technical conference cited on the cover and title page. Papers were selected and subject to review by the editors and conference program committee. Some conference presentations may not be available for publication. The papers published in these proceedings reflect the work and thoughts of the authors and are published herein as submitted. The publisher is not responsible for the validity of the information or for any outcomes resulting from reliance thereon.

Please use the following format to cite material from this book:

Author(s), "Title of Paper," in Lasers in Dentistry XIX, edited by Peter Rechmann, Daniel Fried, Proceedings of SPIE Vol. 8566 (SPIE, Bellingham, WA, 2013) Article CID Number.

ISSN: 1605-7422

ISBN: 9780819493354

Published by

SPIE

P.O. Box 10, Bellingham, Washington 98227-0010 USA

Telephone +1 3606763290 (Pacific Time) · Fax +1 3606471445

SPIE.org

Copyright $@ 2013$, Society of Photo-Optical Instrumentation Engineers.

Copying of material in this book for internal or personal use, or for the internal or personal use of specific clients, beyond the fair use provisions granted by the U.S. Copyright Law is authorized by SPIE subject to payment of copying fees. The Transactional Reporting Service base fee for this volume is $\$ 18.00$ per article (or portion thereof), which should be paid directly to the Copyright Clearance Center (CCC), 222 Rosewood Drive, Danvers, MA 01923. Payment may also be made electronically through $\mathrm{CCC}$ Online at copyright.com. Other copying for republication, resale, advertising or promotion, or any form of systematic or multiple reproduction of any material in this book is prohibited except with permission in writing from the publisher. The CCC fee code is $1605-7422 / 13 / \$ 18.00$.

Printed in the United States of America.

Publication of record for individual papers is online in the SPIE Digital Library.

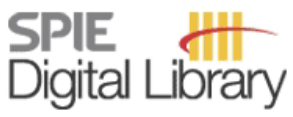

SPIEDigitalLibrary.org

Paper Numbering: Proceedings of SPIE follow an e-First publication model, with papers published first online and then in print and on CD-ROM. Papers are published as they are submitted and meet publication criteria. A unique, consistent, permanent citation identifier (CID) number is assigned to each article at the time of the first publication. Utilization of CIDs allows articles to be fully citable as soon as they are published online, and connects the same identifier to all online, print, and electronic versions of the publication. SPIE uses a six-digit CID article numbering system in which:

- The first four digits correspond to the SPIE volume number.

- The last two digits indicate publication order within the volume using a Base 36 numbering

system employing both numerals and letters. These two-number sets start with 00, 01, 02, 03, 04, $05,06,07,08,09,0 A, 0 B \ldots$. OZ, followed by 10-1Z, 20-2Z, etc.

The CID Number appears on each page of the manuscript. The complete citation is used on the first page, and an abbreviated version on subsequent pages. Numbers in the index correspond to the last two digits of the six-digit CID Number. 


\section{Contents}

vii Conference Committee

\section{SESSION 1 LASERS IN CARIES LESION AND EROSION DETECTION}

856602 Monitoring of enamel lesion remineralization by optical coherence tomography: an alternative approach towards signal analysis [8566-2]

A. Sadr, M. Mandurah, S. Nakashima, Y. Shimada, Y. Kitasako, J. Tagami, Tokyo Medical and Dental Univ. (Japan); Y. Sumi, National Ctr. for Geriatrics and Gerontology (Japan)

856603 Multimodal optical device for early childhood caries: a clinical prototype [8566-3]

L. Zhang, J. S. Ridge, L. Y. Nelson, J. H. Berg, E. J. Seibel, Univ. of Washington (United States)

856604 Clinical monitoring of early caries lesions using cross polarization optical coherence tomography [8566-4]

D. Fried, M. Staninec, C. L. Darling, K. H. Chan, R. B. Pelzner, Univ. of California, San Francisco (United States)

856605 Polarization sensitive camera for the in vitro diagnostic and monitoring of dental erosion [8566-5]

A. Bossen, Bern Univ. of Applied Sciences (Switzerland); E. Rakhmatullina, A. Lussi, Univ. of Bern (Switzerland); C. Meier, Bern Univ. of Applied Sciences (Switzerland)

856606 Methods for monitoring erosion using optical coherence tomography [8566-6]

K. H. Chan, A. C. Chan, C. L. Darling, D. Fried, Univ. of California, San Francisco (United States)

SESSION 2 LASERS IN BIOFILM, TOOTH STRUCTURE, AND MICRO LEAKAGE IMAGING AND TOOTH RECONSTRUCTION

$85660 \mathrm{~A}$ Utilizing optical coherence tomography for CAD/CAM of indirect dental restorations [8566-10]

R. Chityala, Univ. of Minnesota, Twin Cities (United States); C. Vidal, R. Jones, Univ. of Minnesota School of Dentistry (United States)

\section{SESSION 3 LASERS IN HARD TISSUE REMOVAL}

8566 OB Selective excavation of human carious dentin using the nanosecond pulsed laser in 5.8$\mu \mathrm{m}$ wavelength range [8566-1 1 ]

T. Kita, K. Ishii, Osaka Univ. (Japan); K. Yoshikawa, K. Yasuo, K. Yamamoto, Osaka Dental Univ. (Japan); K. Awazu, Osaka Univ. (Japan) 
$85660 \mathrm{C}$ Contact versus non-contact ablation of the artificial enamel caries by Er:YAG and CTH:YAG laser radiation [8566-12]

T. Dostálová, Charles Univ. in Prague (Czech Republic); H. Jelínková, J. Šulc, M. Němec, Czech Technical Univ. in Prague (Czech Republic); M. Bučková, M. Kašparová, Charles Univ. in Prague (Czech Republic); M. Miyagi, Sendai National College of Technology (Japan)

8566 OD A USPL functional system with articulated mirror arm for in-vivo applications in dentistry [8566-13]

F. Schelle, J. Meister, C. Dehn, B. Oehme, C. Bourauel, M. Frentzen, Univ. Dental Clinic Bonn (Germany)

SESSION 4 LASERS IN HARD TISSUE - SELECTIVE CALCULUS REMOVAL, SIDE EFFECTS, ENDODONTICS, CARIES RESISTANCE

$8566 \mathrm{OE}$ The efficacy of selective calculus ablation at $400 \mathrm{~nm}$ : comparison to conventional calculus removal methods [8566-14]

J. E. Schoenly, The Univ. of Toronto (Canada) and Univ. of Rochester (United States) and The Institute of Optics, Univ. of Rochester (United States); W. Seka, Univ. of Rochester (United States) and The Institute of Optics, Univ. of Rochester (United States); G. Romanos, Stony Brook Univ. School of Dental Medicine (United States); P. Rechmann, Univ. of California, San Francisco (United States)

8566 OF Influence of USP laser radiation on cell morphology: HaCat and MG-63 cell lines for bone and soft tissue modelling in dentistry [8566-15]

J. Meister, F. Schelle, I. Beier, C. Bourauel, M. Frentzen, D. Kraus, Univ. Dental Clinic Bonn (Germany)

8566 OG Photodynamic therapy for inactivating endodontic bacterial biofilms and effect of tissue inhibitors on antibacterial efficacy [8566-16]

A. Shrestha, A. Kishen, Univ. of Toronto (Canada)

POSTER SESSION

8566 Ol Imaging early demineralization on tooth occlusional surfaces with a high definition InGaAs camera [8566-18]

W. A. Fried, D. Fried, K. H. Chan, C. L. Darling, Univ. of California, San Francisco (United States)

$8566 \mathrm{OJ}$ Monitoring the remineralization of early simulated lesions using a pH cycling model with CP-OCT [8566-19]

H. Kang, K. Chan, C. L. Darling, D. Fried, Univ. of California, San Francisco (United States)

8566 OK Acoustic comparison of Er,Cr:YSGG laser and dental high speed handpiece for primary anterior tooth preparation [8566-20]

M. Jorden, U.S. Naval Hospital (Japan); J.-W. Chen, Loma Linda Univ. School of Dentistry (United States); E. Easley, Arizona School of Dentistry and Oral Health (United States); Y. Li,

R. Kurti, Loma Linda Univ. School of Dentistry (United States) 
$8566 \mathrm{OL}$ Laser investigation of the non-uniformity of fluorescent species in dental enamel [8566-21] S. U. Tran, J. S. Ridge, L. Y. Nelson, E. J. Seibel, Univ. of Washington (United States)

Author Index

Proc. of SPIE Vol. $8566856601-5$

Downloaded From: https://www.spiedigitallibrary.org/conference-proceedings-of-spie on 26 Apr 2023 Terms of Use: https://www.spiedigitallibrary.org/terms-of-use 
Proc. of SPIE Vol. $8566856601-6$

Downloaded From: https://www.spiedigitallibrary.org/conference-proceedings-of-spie on 26 Apr 2023 Terms of Use: https://www.spiedigitallibrary.org/terms-of-use 


\section{Conference Committee}

Symposium Chairs

James Fujimoto, Massachusetts Institute of Technology (United States)

R. Rox Anderson, Wellman Center for Photomedicine, Massachusetts General Hospital (United States) and Harvard School of Medicine (United States)

Program Track Chair

Brian Jet-Fei Wong, Beckman Laser Institute and Medical Clinic (United States)

Conference Chairs

Peter Rechmann, University of California, San Francisco (United States)

Daniel Fried, University of California, San Francisco (United States)

Conference Program Committee

Gregory B. Altshuler, Palomar Medical Technologies, Inc. (United States)

Tatjána Dostálová, Charles University in Prague (Czech Republic) John D. B. Featherstone, University of California, San Francisco (United States)

David M. Harris, Bio-Medical Consultants, Inc. (United States)

Harvey A. Wigdor, Advocate Illinois Masonic Medical Center (United States)

\section{Session Chairs}

1 Lasers in Caries Lesion and Erosion Detection

Daniel Fried, University of California, San Francisco (United States)

2 Lasers in Biofilm, Tooth Structure, and Micro Leakage Imaging and Tooth Reconstruction

Peter Rechmann, University of California, San Francisco (United States)

3 Lasers in Hard Tissue Removal

Daniel Fried, University of California, San Francisco (United States) 
4 Lasers in Hard Tissue - Selective Calculus Removal, Side Effects, Endodontics, Caries Resistance

Peter Rechmann, University of California, San Francisco (United States) 